\title{
Hubungan Gaya Hidup Dengan Kejadian Hipertensi Pada Pasien Rawat Jalan di Puskesmas Pagesangan Periode Juli 2019
}

\author{
Nur Furqani ${ }^{\text {a, }}{ }^{*}$, Cyntiya Rahmawati ${ }^{\text {a, }}{ }^{\text {, }}$, Melianti ${ }^{\text {a, } 3}$ \\ a,1,2 Dosen Program Studi Diploma Tiga Farmasi, Universitas Muhammadiyah Mataram, Mataram, Indonesia \\ a,3 Mahasiswa Program Studi Diploma Tiga Farmasi, Universitas Muhammadiyah Mataram, Mataram, Indonesia \\ 1 nurfurqani88@gmail.com; ${ }^{2}$ cyntiya.apt@gmail.com; ${ }^{3}$ Melianti088@gmail.com \\ *korespondensi penulis
}

\begin{tabular}{l}
\hline INFO ARTIKEL \\
\hline Diterima : \\
4-I2-20I9 \\
Disetujui : \\
I2-I2-20I9 \\
\hline Kata kunci: \\
Hipertensi; \\
Gaya Hidup; \\
Puskesmas Pagesangan.
\end{tabular}

\section{ABSTRAK}

Hipertensi merupakan tekanan darah tinggi yang bersifat abnormal dengan angka sistolik dan diastolik menunjukan angka lebih tinggi dari $140 / 90 \mathrm{mmHg}$ Hubungan gaya hidup dengan kejadian hipertensi sangat mempengaruhi beberapa kondisi psikis maupun seseorang. Gaya hidup yang sehat menggambarkan pola perilaku sehari-hari yang mengarah pada upaya memelihara kondisi fisik, dan mental sosial berada dalam keadaan positf. Gaya hidup sehat yang meliputi kebiasaan tidur, makan, pengendalian berat badan, tidak merokok, minum-minuman beralkohol, berolahraga secara teratur dan mengendalikan stres, untuk mendapatkan kesehatan yang baik yaitu dengan merubah gaya hidup dalam menjaga kesehatan. Penelitian ini bertujuan untuk mengetahui hubungan gaya hidup dengan kejadian hipertensi pada pasien rawat jalan di Puskesmas Pagesangan periode juli 2019. Penelitian ini menggunakan metode observasi analitik dengan desain penelitian case control dan dianalisi mengunakan uji Chi square Pengambilan data yang dilakukan yaitu dengan cara wawancara langsung dengan menggunakan kuesioner yang diberikan pada responden yang akan diteliti dengan jumlah sampel sebanyak 80 responden diambil berdasarkan kurun waktu penelitian . gaya hidup dengan kejadian hipertensi yang diteliti pada penelitian ini adalah olahraga, merokok, konsumsi ikan asin, konsumsi bayam, konsumsi gorengan, dan konsumsi pisang. Kemudian dianalis dengan menggunakan spss uji chi square. Hasil penelitian penelitian Hubungan Gaya Hidup Dengan Kejadian Hipertensi Pasien Rawat Jalan Di Puskesmas Pagesangan Periode Juli 2019 menunjukan adanya hubungan yang signifikan pada gaya hidup yaitu olahraga $p=0,00$, merokok $p=0,00$, konsumsi bayam $\mathrm{p}=0,00$, konsumsi gorengan $\mathrm{p}=0,00 \mathrm{I}$, konsumsi pisang $\mathrm{p}=0,00 \mathrm{I}$, sedangkan yang menunjukan tidak adanya hubungan yang signifikan adalah gaya hidup konsumsi ikan asin $\mathrm{p}=0,263$.

\section{Keywords :}

Hypertension;

Lifestyle;

community health center of Pagesangan.

\section{ABSTRACT}

Hypertension is an abnormally high blood pressure with systolic and diastolic numbers higher than I40/90mmHg lifestyle relationship with the incidence of hypertension greatly affects several psychological conditions and a person. A healthy lifestyle describes daily behavioral patterns that lead to efforts to maintain physical condition, and social mentality is in a positive state. A healthy lifestyle that includes sleeping, eating, weight control, not smoking, drinking alcoholic beverages, exercising regularly and controlling stress, to get good health by changing lifestyle in maintaining health. This study aims to determine the relationship of lifestyle with the incidence of hypertension in outpatients in the Pagesangan Health Center in July 2019. This study uses analytical observation methods with a case control research design and analyzed using the Chi square test. Data collection was carried out by means of direct interviews using questionnaire given to respondents to be studied with a total sample of 80 respondents taken based on the period of research. lifestyle with the incidence of hypertension studied in this study are exercise, smoking, consumption of salted fish, consumption of spinach, consumption of fried foods, and consumption of 
bananas. Then analyzed using the chi square test spss. The results of the study of the Relationship between Lifestyle and Outpatient Hypertension in the Pagesangan Health Center in the period of July 2019 showed a significant relationship to lifestyle, namely exercise $p=0.00$, smoking $p=0.00$, spinach consumption $p=0.00$, consumption fried food $p=0,001$, consumption of banana $p=0,00 I$, while the one that shows no significant relationship is the lifestyle of salted fish consumption $\mathrm{p}=0,263$.

\section{PENDAHULUAN}

Hipertensi merupakan tekanan darah tinggi yang bersifat abnormal dengan angka sistolik dan diastolik menunjukan angka lebih tinggi dari I40/90mmHg dan diukur paling tidak pada tiga kesempatan yang berbeda. Tekanan darah yang meningkat dan berkepanjangan dapat merusak pembuluh darah di organ target seperti ginjal, jantung, otak dan mata sehingga hipertensi menjadi salah satu faktor utama sebagai penyebab kematian nomor satu di dunia atau atau dikenal sebagai the silent killer (Ardiansyah, 20I2.,DiGiulio, 20I4.,Pustadin, 20I4., dan Smeltzer, 2016). Berdasarkan penyebab hipertensi dibagi menjadi dua yaitu hipertensi primer (esensial) dan hipertensi sekunder, di kalangan masyarakat banyak di jumpai kejadian atau kasus hipertensi esensial. Hipertensi esensial merupakan hipertensi yang penyebabnya tidak diketahui (idiopatik), walaupun dikaiatkan dengan kombinasi faktor gaya hidup seperti kurang bergerak dan pola makan (Pustadatin, 20I4).

Prevalensi hipertensi di dunia menurut WHO tahun 2006 terdapat 972 juta orang atau 26,4\% yang mengalami kejadian hipertensi. Angka ini kemungkinan akan meningkat menjadi 29,2\% ditahun 2025. Dari 972 juta pengidap hipertensi, 333 juta berada di negara maju dan 639 juta sisanya berada di negara sedang berkembang, termaksud Indonesia (Andra 2007). Gaya hidup dapat memicu terjadinya hipertensi. Ini dikarenakan gaya hidup menggambarkan pola prilaku sehari-hari yang mengarah pada upaya memelihara kondisi fisik, mental dan sosial yang meliputi kebiasaan tidur, mengkonsumsi makanan yang tidak sehat, merokok atau bahkan minum-minuman beralkohol (Lisnawati, 20II).

Prevalensi hipertensi di Indonesia yang didapat melalui pengukuran pada kelompok umur $\geq$ I8 tahun sebesar 25,8\%. Prevalensi hipertensi pada setiap propinsi di Indonesia pada kelompok umur $\geq$ I8 tahun tergolong cukup tinggi. (Kemenkes RI, 20I4) Prevalensi terbesar penyakit Hipertensi di NTB terdapat pada penduduk yang bertempat tinggal di perkotaan penyebab utama kematian pada pasien hipertensi adalah komplikasin serebrovaskular, kardiovaskular dan gagal ginjal (Sukandar, E.Y,dkk, 2008). Peningkatan tekanan darah dipengaruhi oleh beberapa faktor risiko antara lain umur, jenis kelamin, riwayat keluarga, genetik (faktor risiko yang tidak dapat diubah/dikontrol) dan gaya hidup seperti kebiasaan merokok, konsumsi garam, konsumsi lemak jenuh, penggunaan jelantah, kebiasaan konsumsi minum-minuman beralkohol, obesitas, kurang aktifitas fisik, stres, penggunaan estrogen (Kemenkes RI, 20I4). Tujuan dari penelitian ini Untuk Mengetahui Hubungan Gaya Hidup Dengan Kejadian Hipertensi Pada Pasien Rawat Jalan Di Puskesmas Pagesangan Periode Juli 2019.

\section{METODE PENELITIAN}

I. Metode penelitian ini adalah penelitian observasi analitik, dengan desain case control. Case control adalah penelitian yang dilakukan dengan cara membandingkan antara dua kelompok yaitu kelompok kasus dan kelompok kontrol (Notoatmodjo, 20I0). Studi kasus kontrol dilakukan dengan mengindentifikasi kelompok kasus dan kelompok kontrol, kemudian secara retrospektif diteliti faktor-faktor resiko yang mungkin dapat menerangkan apakah kasus dan kontrol dapat terkena paparan atau tidak.

2. Tempat dan Waktu penelitian

Penelitian ini dilakukan di Puskesmas Pagesangan Mataram. Penelitian ini dilakukan pada bulan Juli tahun 2019.

3. Alat dan Bahan

Alat pengumpulan data :

a. Lembar persetujuan (Informed consent)

Lembar persetujuan atau Informed consent, dipergunakan untuk mengetahui apakah pasien hipertensi di Puskesmas pagesangan Mataram bersedia menjadi responden atau tidak

b. Kuesioner

Instrumen yang digunakan dalam penelitian ini adalah berupa kuesioner yang berisi pertanyaan tertulis yang digunakan untuk memperoleh informasi dari responden. Kuesioner yang digunakan dalam penelitian ini terdiri dari pertanyaan yaitu: olagraga, merokok, konsumsi ikan asin, konsumsi bayam, konsumsi gorengan, konsumsi pisang. Kuesioner ini diambil dari kuesioner milik Linda Miftahul. J tentang Hubungan Gaya Hidup Dengan Kejadian 
Hipertensi Di Desa Bumiayu Kabupaten Bojonegoro.

4. Jalannya Penelitian (optional)

Dalam proses pengambilan data ada beberapa langkah yang dilakukan oleh peneliti, yaitu:

a. Meminta izin dalam pengambilan data kepada Kepala Puskesmas Pagesangan Mataram.

b. Memilih semua pengunjung yang sesuai dengan kriteria inklusi yang sudah di tetapkan.

c. Meminta pengunjung untuk menandatangani informed concent (persetujuan) jika setuju dijadikan subjek penelitian.

d. Memberikan kuesioner kepada subjek peneliti.

e. Melakukan penyajian data.

\section{HASIL DAN PEMBAHASAN}

Penelitian ini dilaksanakan di Puskesmas Pagesangan pada tanggal I5 sampai 28 Juli tahun 2019, Subjek pada penelitian ini adalah Pasien hipertensi dan tidak hipertensi pasien rawat jalan . Pengambilan data yang dilakukan yaitu sesuai dengan kriteria inklusi dengan cara wawancara langsung dengan menggunakan kuesioner yang diberikan pada responden yang akan diteliti dengan jumlah sampel

\begin{tabular}{|c|l|c|c|}
\hline NO & \multicolumn{1}{|c|}{ VARIABEL } & $\mathrm{N}$ & $\%$ \\
\hline I. & JENIS & & \\
& KELAMIN & 39 & $48,75 \%$ \\
& a. Laki-laki & $4 \mathrm{I}$ & $5 \mathrm{I}, 52 \%$ \\
& b. Perempuan & & \\
\hline 2. & Usia & & \\
& a. $26-35$ tahun & 0 & 0 \\
& b. 36-45 tahun & 9 & $\mathrm{I}$ I,25\% \\
& c. $46-55$ tahun & $2 \mathrm{I}$ & $26,25 \%$ \\
& d.56-65 tahun & $4 \mathrm{I}$ & $5 \mathrm{I}, 52 \%$ \\
& e. $>$ 65 & 9 & $\mathrm{II}, 25 \%$ \\
\hline 3. & Pendidikan & & \\
& a. SD & 6 & $0,75 \%$ \\
& b. SMP & 32 & $0,4 \%$ \\
& c. SMA & 25 & $3 \mathrm{I}, 25 \%$ \\
& d. Perguruan & $\mathrm{I} 7$ & $2 \mathrm{I}, 25 \%$ \\
& tinggi & & \\
\hline 4. & Pekerjaan & & \\
& a. petani & 9 & $\mathrm{II}, 25 \%$ \\
& b. pedagang & $\mathrm{II}$ & $\mathrm{I} 3,75 \%$ \\
& c. pertenak & $\mathrm{I}$ & $0, \mathrm{I} \%$ \\
& d. tidak berkerja & 29 & $36,25 \%$ \\
& e. lain-lain & 30 & $37,5 \%$ \\
\hline
\end{tabular}

sebanyak 80 responden diambil berdasarkan kurun waktu penelitian .

Adapun karateristik responden yang dianalisis pada penelitian ini meliputi jenis kelamin, usia, pendidikan, dan pekerjaan responden, gaya hidup dengan kejadian hipertensi yang diteliti pada penelitian ini adalah olahraga, merokok, konsumsi ikan asin, konsumsi bayam, konsumsi gorengan, dan konsumsi pisang. Kemudian dianalis dengan menggunakan spss uji chis square bertujuan untuk melihat apakah ada hubungan hubungan yang signifikan anatara gaya hidup dengan kejadian hipertensi pasien rawat jalan di Puskesmas Pagesangan Mataram dengan perbandingan signifikan $p=0,05$ jika $<0,05$ maka dinyatakan signifikan jika $>$ $p=0,05$ maka dinyatakan tidak memiliki hubungan yang signifikan. Teknik pengambilan sampel pada penelitian ini menggunakan teknik case control yaitu dengan membandingkan responden yang menderita hipertensi dan tidak menderita hipertensi.

\section{Karateristik responden}

Hubungan Gaya Hidup Dengan Kejadian Hipertensi Berdasarkan gaya hidup dengan kejadian hipertensi penelitian ini diambil sebanyak 80 responden yang memenuhi kriteria inklusi dan eksklusi, gaya hidup pada penelitian ini meliputi (olahraga, kebiasaan merokok, konsumsi ikan asin, konsumsi bayam, konsumsi gorengan, dan konsumsi pisang). Pada setiap gaya hidup memiliki 3 pertanyaan jumlah pertanyaan keseluruhan gaya hidup berjumlah sebanyak I8 pertanyaan dengan memiliki kriteria berdasarkan pertanyaan setiap gaya hidup dan dianalisi mengunakan uji statistika chi square dengan perbandingan $\mathrm{p}=0,05$ dinyatakan signifikan apabila $\mathrm{p}<0,05$ atau ada hubungan yang signifikan . Berikut adalah uraian gaya hidup dengan kejadian hipertensi pada pasien rawat jalan di Puskesmas Pagesangan Kota Mataram.

Tabel 4.2 Tabulasi Olahraga Dengan Kejadian Hipertensi

\begin{tabular}{|c|c|c|c|c|c|c|c|}
\hline \multirow{2}{*}{$\begin{array}{l}\text { Hipert } \\
\text { ensi } \\
\text { merok } \\
\text { ok }\end{array}$} & \multicolumn{2}{|r|}{$\mathrm{Ya}$} & \multicolumn{2}{|c|}{ Tidak } & \multicolumn{2}{|c|}{ Total } & \multirow[t]{2}{*}{$P$} \\
\hline & $\mathrm{N}$ & $\%$ & $\mathrm{~N}$ & $\%$ & $\mathrm{~N}$ & $\%$ & \\
\hline Buruk & $\begin{array}{l}\text { I } \\
7\end{array}$ & $\begin{array}{l}21,2 \\
5 \%\end{array}$ & I & $\begin{array}{l}01,2 \\
5 \%\end{array}$ & $\begin{array}{l}\text { I } \\
8\end{array}$ & $\begin{array}{l}22,5 \\
\%\end{array}$ & \multirow[t]{3}{*}{$\begin{array}{l}0, \\
00\end{array}$} \\
\hline Baik & $\begin{array}{l}2 \\
3\end{array}$ & $\begin{array}{l}28,7 \\
5 \%\end{array}$ & $\begin{array}{l}3 \\
9\end{array}$ & $\begin{array}{l}48,7 \\
5 \%\end{array}$ & $\begin{array}{l}6 \\
2\end{array}$ & $\begin{array}{l}77,5 \\
\%\end{array}$ & \\
\hline Jumlah & $\begin{array}{l}4 \\
0\end{array}$ & & $\begin{array}{l}4 \\
0\end{array}$ & & $\begin{array}{l}8 \\
0\end{array}$ & $\begin{array}{l}\text { I00 } \\
\%\end{array}$ & \\
\hline
\end{tabular}

Berdasarkan tabulasi 4.2 menunjukkan bahwa hubungan kejadian hipertensi dengan aktifitas fisik menunjukkan adanya hubungan yang signifikan dengan perbandingan $p=0,00<p=0,05$, responden yang kategori buruk lebih banyak menggalami 
kejadian hipertensi dibandingkan dengan responden yang berkategori baik, hal ini disebabkan banyaknya responden yang tidak menyadari pentingnya olahraga bagi tubuh terutama untuk mencegah terjadinya hipertensi. Penelitian ini sejalan dengan penelitian yang dilakukan oleh Linda Miftahul J Tahun 2018 bahwa ada hubungan yang signifikan antara kejadian hipertensi dengan olahraga .Penelitian lain yang dilakukan oleh Ina Eriana (20I7) Tentang Hubunagan Gaya Hidup Dengan Kejadian Hipertensi Pada Pegawai Negri Sipil Uin Alauddin menujukan adanya hubungan yang signifikan anatara kejadia hipertensi dengan kejadian hipertensi.

Tabel 4.3 Tabel Tabulasi Merokok Dengan Kejadian Hipertensi

\begin{tabular}{|c|c|c|c|c|c|c|c|}
\hline \multirow{2}{*}{$\begin{array}{c}\text { hipert } \\
\text { ensi } \\
\text { Olahr } \\
\text { aga }\end{array}$} & \multicolumn{2}{|c|}{ Ya } & \multicolumn{2}{|c|}{ Tidak } & \multicolumn{2}{|c|}{ Total } & \multirow{2}{*}{$P$} \\
\hline & $\mathrm{N}$ & $\%$ & $\mathrm{~N}$ & $\%$ & $\mathrm{~N}$ & $\%$ & \\
\hline Baik & $\begin{array}{l}2 \\
5\end{array}$ & $\begin{array}{l}3 \mathrm{I}, 2 \\
5 \%\end{array}$ & 6 & $\begin{array}{l}0,75 \\
\%\end{array}$ & $\begin{array}{l}3 \\
\mathrm{I}\end{array}$ & $\begin{array}{l}38,7 \\
5 \%\end{array}$ & $\begin{array}{l}0, \\
00\end{array}$ \\
\hline Buruk & $\begin{array}{l}\text { I } \\
5\end{array}$ & $\begin{array}{l}\text { I7,5 } \\
\%\end{array}$ & $\begin{array}{l}3 \\
4\end{array}$ & $\begin{array}{l}42,5 \\
5\end{array}$ & $\begin{array}{l}4 \\
9\end{array}$ & $\begin{array}{l}6 \mathrm{I}, 2 \\
5 \%\end{array}$ & \\
\hline $\begin{array}{l}\text { Jumla } \\
\text { h }\end{array}$ & $\begin{array}{l}4 \\
0\end{array}$ & & $\begin{array}{l}4 \\
0\end{array}$ & & $\begin{array}{l}8 \\
0\end{array}$ & $\begin{array}{l}\text { I00 } \\
\%\end{array}$ & \\
\hline
\end{tabular}

Berdasarkan hasil tabulasi tabel 4.3 menujukkan bahwa ada hubungan yang signifikan antara kejadian hipertensi dengan merokok dengan perbandingan $p=0,00<p=0,05$. Penelitian ini menunjukkan bahwa responden yang kategori baik banyak menggalami kejadian hipertensi di bandingkan dengan responden yang kategori buruk. karena pada penelitian ini jumlah responden perempuan lebih banyak dibandingkan dengan responden laki-laki sedikit dengan kejadian hipertensi.

Rokok mengandung senyawa kimia yang sangat berbahaya, terutama nikotin dan karbon monoksida. Zat tersebut dihisap dan kemudian masuk ke dalam aliran darah. Zat tersebut dapat merusak pembuluh darah yang akan menyebabkan aterosklerosis yang meneyebabkan penyempitan pembuluh darah sehingga menyebabkan tekanan dalam dinding arteri meningkat (Depkes. 2008). Karbon monoksida dalam asap rokok akan menggantikan ikatan oksigen dalam darah. Hal tersebut mengakibatkan tekanan darah meningkat karena jantung dipaksa memompa untuk memasukkan oksigen yang cukup ke dalam organ dan jaringan tubuh lainnya. (Thomas, 2000 dalam Hanafi,2016).
Penelitian ini sejalan dengan penelitian yang dilakukan oleh Kim, so dan Sung (2015) menunjukkan bahwa tidak ada hubungan yang signifikan anatara merokok dengan dengan kejadian hipertensi. Perbedaan penelitian yang dilakukan Ainun dkk (2012) yang menyatakan bahwa ada hubungan antara merokok dengan kejadian hipertensi.

Tabel 4.4 Tabulasi Konsumsi Ikan Asin Dengan Kejadian Hipertens

\begin{tabular}{|l|c|c|c|c|c|c|c|}
\hline $\begin{array}{c}\text { Hiper } \\
\text { tensi } \\
\text { ikan } \\
\text { asin }\end{array}$ & \multicolumn{2}{|c|}{ Ya } & \multicolumn{2}{|c|}{ Tidak } & \multicolumn{2}{|c|}{ Total } & \multirow{2}{*}{$P$} \\
\cline { 2 - 6 } & $\mathrm{N}$ & $\%$ & $\mathrm{~N}$ & $\%$ & $\mathrm{~N}$ & $\%$ & \\
\hline Sering & $\mathrm{I}$ & $\begin{array}{l}22, \\
5 \%\end{array}$ & 2 & $\begin{array}{l}28,7 \\
5 \%\end{array}$ & 4 & $\begin{array}{l}5 \mathrm{I}, 2 \\
5 \%\end{array}$ & 0,2 \\
& 8 & $5 \%$ & 3 & $5 \%$ & $\mathrm{I}$ & $5 \%$ & 63 \\
\hline jarang & 2 & 27, & $\mathrm{I}$ & $2 \mathrm{I}, 2$ & 3 & 48,7 & \\
& 2 & $5 \%$ & 7 & $5 \%$ & 9 & $5 \%$ & \\
\cline { 1 - 5 } Jumla & 4 & & 4 & & 8 & $\mathrm{I} 00$ & \\
h & 0 & & 0 & & 0 & $\%$ & \\
\hline
\end{tabular}

Berdasarkan tabel 4.4 menyatakan bahwa tidak adanya hubungan yang signifikan antara konsumsi ikan asin dengan kejadian hipertensi dengan perbadingan $p=0,263>p=0,05$, penelitian ini menunjukan banyaknya reponden yang kategori sering banyak mengalami kejadian hipertensi dibandingkan dengan kategori jarang, Natrium yang terkandung dalam garam dan sumber lainnya seperti ikan asin sebenarnya sangat diperlukan tubuh untuk fungsi otot, syaraf, serta untuk mengelola tekanan dan volume darah.

Natrium yang terkandung dalam garam dan sumber lainnya seperti ikan asin sebenarnya sangat diperlukan tubuh untuk fungsi otot, syaraf, serta untuk mengelola tekanan dan volume darah. Natrium memiliki peran yang sangat penting dalam mengatur keseimbangan asam basah darah, mengatur keseimbangan cairan dalam tubuh, merangsang fungsi syaraf, mengatur kontraksi otot, serta mengatur tekanan osmosis yang menjaga cairan tidak keluar dari darah dan masuk kedalam sel. Pengaruh konsumsi natrium yang berlebihan dapat menyebab komposisi natrium didalam cairan ekstraseluler meningkat. Pengaruh volume cairan yang meningkat menyebabkan meningkatnya volume darah sehingga dapat terjadi hipertensi (Atun, Siswati dan Kurdanti 20I4).

Penelitian ini berbeda dengan penelitian Linda Miftahul J (2018) yang menyatakan bahwa ada hubunagn yang signifikan anatara konsumsi ikan asin dan kejadian hipertensi $p=0,0 I<p=0,05$ 
Tabel 4.5 Tabulasi Konsumsi Bayam Dengan Kejadian Hipertensi

\begin{tabular}{|c|c|c|c|c|c|c|c|}
\hline $\begin{array}{c}\text { Hiperte } \\
\text { nsi } \\
\text { kon.bay } \\
\text { am }\end{array}$ & \multicolumn{2}{|c|}{ Ya } & \multicolumn{2}{c|}{ Tidak } & \multicolumn{2}{|c|}{ Total } & \multirow{2}{*}{$P$} \\
\cline { 2 - 7 } & $\mathrm{N}$ & $\%$ & $\mathrm{~N}$ & $\%$ & $\mathrm{~N}$ & $\%$ & \\
\hline Sering & 2 & $3 \mathrm{I}$, & 0 & 0 & 2 & $\begin{array}{l}3 \mathrm{I}, 25 \\
\%\end{array}$ & $\begin{array}{l}0,0 \\
0\end{array}$ \\
& 5 & 25 & & & 5 & $\%$ \\
\hline Jarang & $\mathrm{I}$ & $\mathrm{I}$, & 4 & 0,5 & 5 & $\begin{array}{l}6,75 \\
\%\end{array}$ & \\
& 5 & 75 & 0 & $\%$ & 5 & $\%$ & \\
\hline Jumlah & 4 & & 4 & & 8 & & \\
& 0 & & 0 & & 0 & & \\
\hline
\end{tabular}

Berdasarkan tabel 4.5 hasil uji statistik chis square menyatakan bahwa ada hubungan yang signifikan antara konsumsi bayam dengan kejadian hipertensi dengan $p=0,00<p=0,05$, kategori jarang mengomsumsi bayam lebih banyak dibandingkan kategori sering. Berdasarkan hasil wawancara yang dilakukan informasi dari responden sebagian mengetahui bahwa konsumsi bayam tidak baik untuk kejadian hipertensi.

Jovanovski et ali (2015) menyatakan bahwa bayam menggandung kadar nitrat yang tinggi sehingga dapat mempengaruhi bentuk gelombang arteri yang menujukan kekakuan arteri, serta tekanan darah pusat dan periver.

Penelitian ini sejalan dengan penelitian Afifah (2016) yang menyatakan bahwa tidak ada hubungan yang signifikan anatara hubungan gaya hidup dengan kejadian hipertensi pada pasien rawat jalan di rumah sakit Penebahan Senopati Bantul Yogyakarta. Penelitian ini tidak sejalan dengan penelitian yang dilakukan oleh Linda Miftahul. J (2018) yaitu ada hubungan yang signifikan anatara kejadian hipertensi dengan kejadian hipertensi.

Tabel 4.6 Tabulasi Gorengan Dengan Kejadian Hipertensi

\begin{tabular}{|c|c|c|c|c|c|c|c|}
\hline \multirow{2}{*}{$\begin{array}{l}\text { Hipert } \\
\text { ensi } \\
\text { goreng } \\
\text { an }\end{array}$} & \multicolumn{2}{|c|}{$\mathrm{Ya}$} & \multicolumn{2}{|c|}{ Tidak } & \multicolumn{2}{|c|}{ Total } & \multirow[b]{2}{*}{$P$} \\
\hline & $\mathrm{N}$ & $\%$ & $\mathrm{~N}$ & $\%$ & $\mathrm{~N}$ & $\%$ & \\
\hline Sering & 0 & 0 & $\begin{array}{l}\mathrm{I} \\
0\end{array}$ & $\begin{array}{l}\mathrm{I} 2,5 \\
\%\end{array}$ & $\begin{array}{l}\mathrm{I} \\
0\end{array}$ & $\begin{array}{l}\mathrm{I} 2,5 \\
\%\end{array}$ & \multirow[t]{3}{*}{$\begin{array}{l}0,0 \\
0 I\end{array}$} \\
\hline Jarang & $\begin{array}{l}4 \\
0\end{array}$ & $\begin{array}{l}0,5 \\
\%\end{array}$ & $\begin{array}{l}3 \\
0\end{array}$ & $\begin{array}{l}37,5 \\
\%\end{array}$ & $\begin{array}{l}7 \\
0\end{array}$ & $\begin{array}{l}87,5 \\
\%\end{array}$ & \\
\hline Jumlah & $\begin{array}{l}4 \\
0\end{array}$ & & $\begin{array}{l}4 \\
0\end{array}$ & & $\begin{array}{l}8 \\
0\end{array}$ & $\begin{array}{l}\text { I00 } \\
\%\end{array}$ & \\
\hline
\end{tabular}

Berdasarkan tabel 4.5 hasil uji statistik chis square pada penelitian ini adalah terdapat hubungan yang signifikan antara kejadian hipertensi dengan konsumsi gorengan dengan $p=0,00 I<p=0,05$ dengan kategori jarang lebih banyak dibandingkan kategori sering, menurut pemahaman dari responden bahwa gorengan merupakan makanan yang banyak digemari di kalangan masyarakat akan tetapi ada sebagian orang yang menyadari bahwa konsumsi gorengan tidak baik untuk penderita hipertensi.

Konsumsi gorengan yang mengandung lemak jenuh yang dikonsumsi seperti gorengan yang dikonsumsi akan dipecah menajadi Kolestrol Low Densisty Lipoprotein (LLD). Kadar kolestrol yang tinggi dapat membentuk plak pada permukaan dinding pembuluh darah arteri, sehingga dapat menyebabkan diameter pembuluh darah mengecil dan dapat menyebabkan diameter pembuluh darah menyebabkan lumen pembuluh darah semakin sempit dan kurang elastisitasnya sehingga dapat mengakibatkan tekanan darah tinggi. Menurut Sobour et al (2016)

Penelitian ini tidak sejalan dengan penelitian Linda Miftahul j (2018) menyatakan bahwa tidak ada hubungan yang signifikan antara kejadian hipertensi dengan konsumsi gorengan $p=0,23>p=0,05$. Penelitian ini tidak sejalan dengan penelitian yang dilakukan oleh Lidayati dan Kartini (20I4) yang menyatakan tidak ada hubungan kejadian hipertensi.

Tabel 4.7 Tabulasi Konsumsi Pisang Dengan Kejadian Hipertensi

\begin{tabular}{|l|l|l|l|l|l|l|l|}
\hline \multirow{2}{*}{$\begin{array}{c}\text { Hipertensi } \\
\text { pisang }\end{array}$} & \multicolumn{2}{|c|}{ Ya } & \multicolumn{2}{c|}{ Tidak } & \multicolumn{2}{c|}{ Total } & \multirow{2}{*}{$P$} \\
\cline { 2 - 7 } & $\mathrm{N}$ & $\%$ & $\mathrm{~N}$ & $\%$ & $\mathrm{~N}$ & $\%$ & \\
\hline Jarang & 40 & & 25 & & 65 & & \multirow{2}{*}{$0.00 \mathrm{I}$} \\
\hline Sering & 0 & & $\mathrm{I} 5$ & & $\mathrm{I} 5$ & & \\
\hline Jumlah & 40 & & 40 & & 80 & & \\
\hline
\end{tabular}

Berdasarkan hasil analisis $U_{j i}$ Chis Square pada tabel 4.6 menyatakan bahwa ada hubungan yang signifikan antara konsumsi buah pisang dengan kejadian hipertensi dengan perbandingan $p=0,00 I<$ $p=0.05$ Dari hasil analis tersebut responden yang kategori jarang banyak menggalami kejadian hipertensi dibandingkan dengan responden yang kategori sering mengonsumsi buah pisang.

Pada penelitian ini pisang merupakan faktor protektif kejadian hipertensi konsumsi pisang secara signifikan dapat menurunkan tekanan darah karena mengandung kalium, dapat menurunkan tekanan darah seseorang karena kalium berperan untuk mengurangi sekresi renin yang menyebabkan penurunan Angiostensin Converting Enzyme Inhibitor (ACE-I). Penurunan angiotensin dapat menyebabkan penurunan aldosterone, sehingga reabsorbsi natrium dan air kedalam darah berkurang. Sutria dan Insani (2016). Penelitian ini tidak sejalan dengan penelitian Linda Miftahuj j (2018) yang menyatakan ada hubungan yang signifikan anatara 
kejadian hipertensi dengan konsumsi pisang dengan $p=0,02<p=0,05$. Sedang penelitian yang dilakukan oleh Afifah (2016) yang menyatakan bahwa ada hubungan yang signifikan antara keajdian hipertensi dengan konsumsi pisang .

\section{SIMPULAN}

Kesimpulan dari penelitian Hubungan Gaya Hidup Dengan Kejadian Hipertensi Pasien Rawat Jalan Di Puskesmas Pagesangan Periode Juli 2019. menunjukan adanya hubungan yang signifikan pada gaya hidup yaitu olahraga $p=0,00$, merokok $p=0,00$, konsumsi bayam $\mathrm{p}=0,00$, konsumsi gorengan $\mathrm{p}=0,00 \mathrm{I}$, konsumsi pisang $\mathrm{p}=0,00 \mathrm{I}$, sedangkan yang menunjukan tidak adanya hubungan yang signifikan adalah gaya hidup konsumsi ikan asin $p=0,263$.

\section{REFERENSI}

Ardiansyah, 20I2.,Digiulio, 20I4.,Pustadin, 20I4., Dan Smeltzer, 2016). Pengertian Hipertensi, Jakarta.

Armilawati. 2007. Tekanan Darah Akan Lebih Tinggi Pada Saat Melakukan Aktivitas Fisik Dan Lebih Rendah Ketika Beristarahat. Jakarta.

Ainun Dkk. Hubungan Merokok Dengan Kejadian Hipertensi. Jakarta

Atun, siswati,dan kurdanti. Pentingnya peran natrium dalam mengatur keseimbangan asam darah. Jakarta.

Affifah.2016 Hubungan Konsumsi Bayam Dengan Kejadian Hipertensi. Jakarta

Aprianti. M. 20I2. Meracik Sendri Obat Dan Menu Penderita Darah Tinggi. Yogyakarta : Pustaka Baru Press.

Benson dan Casey, 2006. Hubungan kejadian hipertensi dengan jenis kelamin. inggris

Budiman, H. I999. Faktor Penyebab Hipertensi. Jakarta.

Bimo, Walgito. 2010 : 72. Pengertian Kuosioner. Jakarta.

Budistio, M. 200I. Asupan Natrium Yang Tinggi Menyebabkan Meningkatnya Tekanan Darah, Jakata.

Crea, 2008 dalam Pusparani 2016. Hubungan kebiasaan konsumsi kopi dengan kejadian hipertensi.

Dali, Marta. 2005. Menyatakan Bahwa Ada Hubungan Antara Aktivitas Fisik Dengan Kejadian Hipertensi, Dan Individu Yang Kurang Aktif Mempuyai Resiko Menderita Hupertensi Sebesar 30-50\%. Jakarta.

Depkes. 2008, kandungan senyawa kimia dalam rokok
Gunawan. 200I. Obat Vasodilator Dapat Langsung Mengembangkan Dinding Arteriol Sehingga Daya Tahan Pembuluh Perifer Berkurang Dan Tekanan Darah Menurun. Jakarta.

H, Alfian Yusuf, Fathurrahman, Magdalena Tahun 20I5. Meneliti Tentang Hubungan Gaya Hidup Dengan Hipertensi Pada Pengunjung Puskesmas Teluk Dalam Banjarmasin.

Irza. 2009. Asupan Lemak Jenuh Yang Kemudian Menyebabkan Hipertensi. Inggris.

I, Gusti. Ketut, Gede Ngurah (20I4) Meneliti Tentang Gaya Hidup Penderita Hipertensi Di Puskesmas I Dempasar Selatan.

Ina Eriana 2017. Hubungan gaya hidup dengan kejadiaan hipertensi pada pegawai negri sipil UIN Alaudin Makasar 2017

Jaya. 2009. Stres Merupakan Salah Satu Faktor Penyebab Terjadinya Hipertensi, Jakarta.

Kemenkes RI. 20I4. Prevalensi Hipertensi Pada Setiap Propinsi Di Indonesia Jakarta.

Kemenkes RI. 20I4, Prevalensi Terbesar Penyakit Hipertensi Di Sukandar, E.Y,Dkk, 2008.

Kotchen et al., 2006. Epidemiologi Menunjukkan Bahwa Terdapat Hubungan Bermakna Antara Tingginya Asupan Lemak Jenuh Dengan Tekanan Darah. Inggris.

Linda, Miftahul J Agustus 20I7. Meneliti Tentang Hubungan Gaya Hidup Dengan Kejadian Hipertensi Di Desa Bumiayu Kabupaten Bojonegoro.

Lisnawati, Notoadmojo. 2005. Menyebutkan Bahwa Perilaku Sehat (Healty Beha Vior) Adalah Perilaku Atau Kegiatan-Kegiatan Yang Berkaitan Dengan Upaya Mempertahankan Dan Meningkatkan Kesehatan. Jakarta.

Lidiawati Dan Kartini, A (20I4). Hubungan Asupan Asam Lemak Jenuh Dan Natrium Dengan Kejadian Hipertensi Pada Wanita Menopause Di Kelurahan Bojongsalaman, Jurnal Of Nutrium College, 3(4), 6I2-6I9.

Muhammadun. 2010. Hidup Bersama Hipertensi. Yogyakarta: In-Booka.

Muhammadun. 20I0. Hipertensi Tidak Memberikan Gejala Atau Simptom Pada Tingkat Awal, Jakarta.

Muhammadun. 20I0. Klasifikasi Dan Tindak Lanjut Hipertensi. Jakarta.

Muhammadun. 20I0. Gaya Hidup Yang Dapat Memicu Terjadinya Hipertensi, Jakarta.

Maulana. 2009. Yang Menyetakan Bahwa Untuk Mendapatkan Kesehatan Yang Prima Jalan Terbaik Adalah Dengan Merubah Gaya Hidup Yang Terlihat Dari Aktivitasnya Dalam Menjaga Kesehtan, Jakarta. 
Muhammadun. 20I0. Tujuan Pengelolaan Krisis Hipertensi Adalah Menurunkan Tekanan Darah Secara Cepat Dan Seaman Mungkin Untuk Menyelamatkan Jiwa Penderita. Jakarta.

Mac Mahon S. Et al, 2004 hubungan kebiasaan olahraga dengan kejadian hipertensi.

Palmer A. 2007. Tekanan Darah Tinggi, Jakarta: Erlangga.

Prodjosudjadi, W. 2000. The Joint National Committee On Preventional, Detection, Evaluation And Treatment Of High Blood Pressure (Jnc) Membuat Klasifikasi Membagi Hipertensi Menjadi Tingkat Satu Dan Tingkat Dua, Inggris.

Pudiastuti. 2013. Pengobatan Hipertensi Dapat Dilakukan Dengan Dua Cara Yaitu Non Farmakologi (Perubahan Gaya Hidup) Dan Farmakologi. Jakarta. Puspitorini. 2009. Dan Susilo. 20II. Jenis Makanan Yang Menyebabkan Hipertensi Yaitu Makanan Yang Siap Saji Yang Mengandung Pengawet, Kadar Garam Yang Terlalu Tinggin Dalam Makanan Kelebihan Komsumsi Lemak. Jakarta.

Pusparani.20I6 penggaruh aktifitas fisik dengan kejadian hipertensi. Jakarta

Qiarino, 200I4 hubungan aktivitas fisik dengan kejadian hipertensi. Jakarta

Sudabutar dan Winguna. I990. Definisi Hipertensi, Jakarta.

Sianturi. 2003. Faktor Yang Dapat Menghubungkan Darah Tinggi Merupakan Kondisi Degeneratif Yang Disebabkan Oleh Diet Beradab Dan Cara Hidup Yang Berbudaya, Jakata.

Shanty. 20II.Penyebabnya Hipertensi Dapat Dibedakan Oleh Faktor Esensial Dan Sekunder, Jakarta.

Shanty. 20I I. Hipertensi Dapat Berpotensi Menjadi Komplikasi Berbagai Penyakit, Jakarta.

Sakinah. 2002. Gaya Hidup Adalah Pola Hidup Seseorang Di Dunia Yang Diekspresikan Dalam Aktifitas, Minat Dan Opininya, Jakarta.

Sakinah. 2002. Gaya Hidup Menggambarkan Keseluruhan Diri Seseorang Yang Berinteraksi Dengan Lingkungannya, Jakarta.

Sustrani. 2006. Mengomsumsi Kafein Secara Teratur Sepanjang Hari Mempuyai Tekananan Darah Rata-Rata Lebih Tinggi Dibandingkan Dengan Kalau Merekan Tidak Mengomsumsi Sama Sekali. Jakarta.
Sugiyono. 20II. Defenisi Variabe Dependent dan independent. Jakarta.

Slovin. 1960. Defenisi penggunaan Rumus Slovin. Jakarta.

Sutanto. 20I0. Ilmu Penyakit Dalam Edisi Ketiga Jilid 2. Jakarta: Fkui.

Suiraokao.20I2 pentingnya aktifitas fisik terhadap kejadian hipertensi

So dan Sung. 2015 Hubungan Kebiasaan Merokok Dengam Kejadian Hipertensi. Korea.

Who Prevalensi Hipertensi Di Dunia Tahun 2006 Terdapat 972 Juta Orang Atau 26,4\% Yang Mengalami Kejadian Hipertensi.

Thomas. 2000 dalam Hanafi 2016. Hubungan konsumsi penggunaan rokok dengan kejadian hipertensi. 